\title{
FAKTOR PERSALINAN KALA 1 LAMA DI PUSKESMAS KETUWAN BLORA
}

\author{
Dwi Susilowati ${ }^{1}$, Dewi Andang Prastika ${ }^{2}$, Listyaning Eko Martanti ${ }^{3}$ \\ 1,2,3 Jurusan Kebidanan Poltekkes Kemenkes Semarang, Indonesia
}

\begin{abstract}
The first stage of labor includes a prolonged latent phase and a prolonged active phase. Long-term delivery always poses risks and complications for both the mother and the fetus in her womb and can be fatal if not treated properly. Based on data from Ketuwan Health Center from January 2020 to December 2020, there were 37 cases of prolonged first stage labor out of 159 cases of labor. The purpose of this study was to determine the factors associated with the incidence of prolonged first stage of labor at the Ketuwan Health Center, Blora Regency which included maternal age, education, parity, his and the weight of the fetus. This type of research is quantitative analytic with a case control research design, using a retrospective approach and using a proportional random sampling technique. The number of samples was 37 cases and 37 controls. Data analysis was carried out univariate and bivariate using the Odds Ratio test. The results showed that the factors associated with the incidence of prolonged first stageof labor were Age $(p=0.403 ; O R=2.121)$, Education $(p=0.627 ; O R=0.789)$, Parity $(p=0.011 ; O R=3.544)$, Contraction $(p=0.000 ; O R=0.072)$, Fetal Weight $(p=1,000 ; O R=1,000)$. The conclusion of this study is that the factors associated with the incidence of prolonged first stage labor include parity and his, while age), education, and fetal weight do not have a significant relationship with the incidence of prolonged first stage labor. The advice given is to establish a definite diagnosis and make the right decisions to reduce the risk to the mother and fetus
\end{abstract}

Keywords : Labor; prolonged first stage of labor 


\section{PENDAHULUAN}

Persalinan adalah proses alami yang akan berlangsung dengan sendirinya, tetapi persalinan pada manusia setiap saat terancam penyulit yang membahayakan ibu maupun janinnya sehingga memerlukan pengawasan pertolongan dan pelayanan fasilitas yang memadai (Manuaba, 2010). Persalinan merupakan salah satu proses pengeluaran hasil konsepsi janin atau plasenta yang dapat hidup di dunia luar, dari rahim menuju jalan lahir atau dengan jalan lain (Mochtar, 2011)

Persalinan lama adalah persalinan yang berjalan lebih dari 24 jam untuk primigravida dan atau 18 jam untuk multigravida (Mochtar, 2011), masalah yang terjadi pada persalinan lama adalah fase laten lebih dari 8 jam. Persalinan telah berlangsung 12 jam atau lebih bayi belum lahir. Dilatasi serviks di kanan garis waspada pada persalinan fase aktif (Saifuddin, 2009).

Faktor terjadinya persalinan lama di bagi menjadi dua faktor yaitu faktor penyebab dan faktor resiko, faktor penyebab: his, mal presentasi dan mal posisi, janin besar, panggul sempit, kelainan serviks dan vagina, disproporsi fetovelvik, dan ketuban pecah dini, dan faktor resiko: analgesik dan anastesis berlebihan, paritas, usia, wanita dependen, respons stres, pembatasan mobilitas, dan puasa ketat (Oxorn, 2010). Persalinan kala I lama selalu memberi resiko dan penyulit baik bagi ibu atau janin yang sedang di kandungnya dan bisa berakibat fatal bila tidak di lakukan penanganan yang tepat Berdasarkan data dari UPTD Puskesmas Ketuwan dari bulan Januari 2020 sd Desember 2020 terdapat 159 kasus persalinan di mana terdapat kasus pasien di rujuk sebesar 96 kasus, terdiri dari persalinan di rujuk pada Kala I ada 80 kasus, Kala II ada 8 kasus Kala III ada 4 kasus dan kala IV ada 1 kasus. Dari 80 kasus persalinan di rujuk pada kala I, 37 kasus karena kala I lama,11 kasus karena PEB, 22 kasus karena KPD, dan kelainan letak ada 5.

Menurut hasil penelitian Riyanto (2014) menunjukkan terdapat hubungan antara faktor partus lama dengan faktor his $(p=0,000 ; \quad P O R=13,008, \quad$ Cl $95 \%$ : (4,435-38,149)), paritas $\quad(p=0,036$; $\mathrm{POR}=2,186$, Cl 95\%: 1,103-4,332), dan usia ibu ( $p=0,000$; POR=16,242, Cl 95\%: 5,092-51,811), sedangkan faktor KPD tidak ada hubungan $(p=0,783)$ (Riyanto, 2014).

Hasil penelitian yang hampir sama yang di lakukan oleh Lusiana Gultom menunjukkan ada hubungan yang bermakna antara partus lama dengan faktor umur $(p=0,002$, OR=3,586), paritas $(p=0,000, \quad O R=7,013)$, Kelainan his $(p=0,000, O R=35,909), \operatorname{CPD}(p=0,000)$, KPD dengan $(p=0,001, \quad O R=15,33)$, Kelainan letak janin $(p=0,000, \quad O R=$ 13,00)(Gultom, 2014), Sedangkan menurut penelitian dari H.Astriana et.all didapatkan ada hubungan partus lama 
dengan faktor umur ibu ( $p$ value 0.002 ; OR 2.027), paritas ( $p$ value 0.001 ; OR 2.170), janin besar ( $p$ value 0.005 ; OR 2.005) (Astriana, Ratna Dewi Putri, 2015). Adapun tujuan dari penelitian ini adalah Mengetahui kejadian Persalinan Kala I lama dan faktor-faktor yang mempengaruhi kejadian Persalinan Kala I lama di UPTD Puskesmas Ketuwan Kabupaten Blora.

\section{METODOLOGI PENELITIAN}

Penelitian ini menggunakan jenis analitik kuantitatif yang dilakukan secara case control. Penelitian dilakukan di UPTD Puskesmas Ketuwan. Populasi penelitian ini seluruh ibu bersalin yang ada di Puskesmas Ketuwan tahun 2020. Teknik pengambilan sampel di bagi menjadi 2 yaitu sampel kasus dan sampel kontrol.

Untuk sampel kasus persalinan kala I lama menggunakan tehnik total sampling seluruh ibu bersalin yang mengalami kejadian persalinan kala I lama di UPTD Puskesmas Ketuwan pada tahun 2020 sebanya 37 ibu bersalin, sedangkan untuk kasus kontrol menggunakan tehnik random sampling, yaitu pengambilan sampel secara random atau acak dengan pengundian dari seluruh ibu bersalin normal di UPTD Puskesmas ketuwan pada tahun 2020 yaitu sebanyak 63 ibu bersalin normal di ambil 37 ibu bersalin normal. Variabel independent pada penelitian ini adalah umur ibu, paritas, pendidikan, his dan berat janin. Variabel dependennya adalah perilaku Persalinan Kala I lama. Analisa univariat menggunakan distribusi frekuensi dan Analisa Bivariat dengan uji statistik Odds Ratio.

\section{HASIL PENELITIAN DAN BAHASAN}

Tabel.1 Karakteristik Responden berdasarkan Faktor umur ibu, pendidikan, paritas, his dan berat bayi lahir

\begin{tabular}{|c|c|}
\hline Karakteristik & $\mathbf{N}(\%)$ \\
\hline \multicolumn{2}{|l|}{ Umur } \\
\hline $\begin{array}{l}\text { Reproduksi Tidak Sehat } \\
\text { (<20 Th, }>35 \text { Th) }\end{array}$ & $6(8,1 \%)$ \\
\hline $\begin{array}{l}\text { Reproduksi Sehat (20-35 } \\
\text { Th) }\end{array}$ & $68(91,9 \%)$ \\
\hline Jumlah & $74(100 \%)$ \\
\hline \multicolumn{2}{|l|}{ Pendidikan } \\
\hline Dasar-Menengah & 69 (93,2\%) \\
\hline PT & $5(6,8 \%)$ \\
\hline Jumlah & $74(100 \%)$ \\
\hline \multicolumn{2}{|l|}{ Paritas } \\
\hline Primipara & $31(41,9 \%)$ \\
\hline Multipara & $43(38,1 \%)$ \\
\hline Jumlah & $74(100 \%)$ \\
\hline \multicolumn{2}{|l|}{ His } \\
\hline Normal $\left(3 \times 10^{\prime}, 40 "\right)$ & $33(44,6 \%)$ \\
\hline Lemah $\left(<3 \times 10^{\prime}, 40 "\right)$ & $41(55,4 \%)$ \\
\hline Jumlah & $74(100 \%)$ \\
\hline \multicolumn{2}{|l|}{ Berat Bayi Lahir } \\
\hline Normal (2.500-4.000 gr) & $72(97,3 \%)$ \\
\hline $\begin{array}{l}\text { Tidak Normal } \\
(<2.500,>4.000 \mathrm{gr})\end{array}$ & $2(2,7 \%)$ \\
\hline Jumlah & $74(100 \%)$ \\
\hline
\end{tabular}


Tabel .2 Hubungan Antara Variabel Independent Kejadian Persalinan Kala I Lama dengan Variabel Dependen umur ibu, pendidikan, paritas, his dan berat bayi lahir

\begin{tabular}{|c|c|c|c|c|c|c|c|c|}
\hline & \multicolumn{4}{|c|}{$\begin{array}{c}\text { Kejadian Persalinan } \\
\text { Kala I lama }\end{array}$} & \multirow{2}{*}{\multicolumn{2}{|c|}{ Jumlah }} & \multirow{2}{*}{$\begin{array}{l}\text { Odds } \\
\text { Ratio }\end{array}$} & \multirow{2}{*}{$\begin{array}{c}P \\
\text { value }\end{array}$} \\
\hline & \multicolumn{2}{|c|}{ Ya } & \multicolumn{2}{|c|}{ Tidak } & & & & \\
\hline & $\mathbf{N}$ & $\%$ & $\mathbf{N}$ & $\%$ & $\mathbf{N}$ & $\%$ & \multirow{5}{*}{2.121} & \multirow{5}{*}{0.674} \\
\hline Faktor Umur & & & & & & & & \\
\hline $\begin{array}{l}\text { Reproduksi tidak sehat } \\
(<20 \text { th, }>35 \text { th) }\end{array}$ & 4 & 5,4 & 2 & 2,7 & 6 & 8,1 & & \\
\hline $\begin{array}{l}\text { Reproduksi sehat (20- } \\
35 \text { th) }\end{array}$ & 33 & 44,6 & 35 & 47,3 & 68 & 91,9 & & \\
\hline Jumlah & 37 & 50 & 37 & 50 & 74 & 100 & & \\
\hline \multicolumn{7}{|l|}{ Faktor Pendidikan } & \multirow{4}{*}{0.648} & \multirow{4}{*}{1.000} \\
\hline Dasar-Menengah & 34 & 45,9 & 35 & 47,3 & 69 & 93,2 & & \\
\hline PT & 3 & 4,1 & 2 & 2,7 & 5 & 6,8 & & \\
\hline Jumlah & 37 & 50 & 37 & 50 & 74 & 100 & & \\
\hline \multicolumn{7}{|l|}{ Paritas } & \multirow{4}{*}{3.176} & \multirow{4}{*}{0.032} \\
\hline Primipara & 21 & 28,4 & 10 & 13,5 & 31 & 41,9 & & \\
\hline Multipara & 16 & 21,6 & 27 & 36,5 & 43 & 58,1 & & \\
\hline Jumlah & 37 & 50 & 37 & 50 & 74 & 100 & & \\
\hline \multicolumn{7}{|l|}{ HIS } & \multirow{4}{*}{13,950} & \\
\hline Lemah (<3X10',40") & 31 & 41,9 & 10 & 13,5 & 58 & 55,4 & & \\
\hline Normal (3X10',40") & 6 & 8,1 & 27 & 36,5 & 33 & 44,6 & & \\
\hline Jumlah & 37 & 50 & 37 & 50 & 74 & 100 & & 0.000 \\
\hline \multicolumn{9}{|l|}{ Berat Bayi Lahir } \\
\hline $\begin{array}{l}\text { Tidak normal Normal } \\
(<2.500,>4.000 \mathrm{gr})\end{array}$ & 1 & 1,4 & 1 & 1,4 & 2 & 2,8 & 1.000 & 1.000 \\
\hline Normal $(2.500-4.000 \mathrm{gr})$ & 36 & 48,6 & 36 & 48,6 & 72 & 97,2 & & \\
\hline Total & 37 & 50 & 37 & 50 & 74 & 100 & & \\
\hline
\end{tabular}

\section{Faktor Umur Ibu}

Inkoordinasi kontrakasi uterus adalah keadaan dimana tonus otot uterus meningkat, juga di luar his dan kontraksinya tidak berlangsung seperti biasa karena tidak ada singkronisasi kontrakasi bagian-bagiannya. Tidak ada koordinasi antara kontraksi bagian atas, tengah dan bawah menyebabkan his tidak efisien dalam mengadakan pembukaan (Saifuddin,2010). Ibu berumur $\leq$ dari 20 tahun dan $\geq 35$ tahun di anggap beresiko terhadap kelainan his. Usia $\leq 20$ tahun respon hormonal tubuh belum berfungsi maksimal oleh karena fungsi sistem reproduksi yang belum siap menerima kehamilan. Penelitian oleh Pawzner menyimpulkan bahwa induksi persalinan meningkat pada kasus multipara $\leq 20$ tahun oleh karena uterus kurang siap untuk persalinan karena serviks belum matang. Usia $\geq 35$ tahun dapat menyebabkan kelainan his oleh karena adanya kemunduran fungsi dan efisiensi kontraksi spontan miomametrium oleh karena menuanya jaringan reproduksi sehingga menyebabkan terjadinya 
persalinan lama (Cunningham, 2013). Hasil penelitian ini menunjukkan bahwa ibu bersalin di UPTD Puskesmas Ketuwan pada rentang umur reproduksi tidak sehat (umur $\leq 20$ tahun> 35 tahun) sebanyak 6 responden $(8,1 \%)$ yang melengalami kejadian persalinan kala I lama ada sebanyak 4 responden $(5,4 \%)$ dan yang bersalin normal ada sebanyak 2 responden $(2,7)$, sedangkan yang pada umur reproduktif sehat (usia $20-35$ tahun) terdapat 68 responden $(91,9 \%)$ yang mengalami kejadian persalinan kala I lama ada 33 responden (44,6\%) dan yang bersalin normal ada 35 responden $(47,3 \%)$. Hal ini berarti sebagian besar yaitu $91,9 \%$ ibu bersalin yang ada di UPTD Puskesmas Ketuwan berusia di rentang umur reproduksi sehat dan yang pada rentang umur reproduksi tidak sehat hanya $8,1 \%$.

Hasil pada uji statistik bivariat hubungan Hubungan antara Umur responden dengan kejadian persalinan kala I lama di UPTD Puskesmas Ketuwan di dapatkan nilai P-Valuenya 0,403 di mana nilai ini lebih besar dari nilai signifikansi sebesar $5 \%$ atau 0,05 yang artinya tidak ada hubungan antara Umur responden dengan kejadian persalin kala I lama, hal ini di karenakan responden penelitian dari kriteria umur sebagian besar terdapat pada rentang umur reproduktif sehat (usia 20 - 35 tahun) yaitu sebesar 68 responden (91,9\%) sedangkan rentang umur reproduksi tidak sehat (umur $\leq 20$ tahun $>35$ tahun) hanya sebanyak 6 responden (8,1\%). Penelitian ini sejalan dengan penelitian yang di lakukan oleh Soviyati, 2016 yang berjudul Faktor-faktor yang berhubungan dengan lama Persalinan di RSUD'45 Kuningan Jawa Barat tahun 2015 (Soviyati, 2016) yang menyatakan bahwa hasil analisisnya menunjukkan hasil Odd Ratio (OR) sebesar 0,9 dapat diartikan ibu yang berumur antara 20 - 35 tahun 0,9 kali lebih besar akan melahirkan dengan lama persalinan $>18$ jam. Hasil analisa dari $p$ value umur ibu $(1,000)$ lebih besar dari $0,05$ ( $p<0,05)$ maka tidak terdapat hubungan antara umur ibu dengan lama persalinan, namun penelitian ini tidak sejalan dengan penelitian yang di lakukan oleh Ardhiyanti \& Susanti, 2016 yang berjudul Faktor Ibu yang berhubungan dengan kejadian Persalinan lama di RSUD Arifin Achmad Pekan Baru (Ardhiyanti \& Susanti, 2016) yang menyatakan bahwa lbu yang berusia <20 tahun atau >35 tahun lebih beresiko mengalami persalinan lama di bandingkan ibu yang berusia 20-30 tahun

\section{Faktor Pendidikan}

Hasil penelitian ini tidak sejalan dengan penelitian yang di lakukan Soviyati, 2016 yang berjudul Faktorfaktor yang berhubungan dengan lama Persalinan di RSUD'45 Kuningan Jawa Barat tahun 2015 (Soviyati, 2016), yang menyatakan terdapat hubungan antara pendidikan dengan lama persalinan. 
Rendahnya pendidikan seorang ibu dikaitkan dengan kemiskinan, kebodohan serat kurangnya pengetahuan tentang pentingnya menjaga kehamilan dan persiapan persalinan merupakan faktor sosial budaya yang ikut berperan dalam tingginya angka kematian maternal (Winkjosastro,2011)

Hasil penelitian ini menunjukkan bahwa ibu bersalin di UPTD Puskesmas Ketuwanyang memiliki pendidikan rentang Dasar-Menengah sebanyak 69 responden $(93,2 \%)$ yang mengalami kejadian persalinan kala I lama ada sebanyak 34 responden (45,9\%) dan yang bersalin normal ada sebanyak 35 responden $(47,3 \%)$, sedangkan yang berpendidikan Perguruan tinggi terdapat 5 responden $(6,8 \%)$ yang mengalami kejadian persalinan kala I lama ada 3 responden $(4,1 \%)$ dan yang bersalin normal ada 2 responden $(2,7 \%)$. Yang artinya bahwa mayoritas ibu bersalin yang ada di UPTD Puskesmas Ketuwan memiliki pendidikan rentang Dasar-Menengah yaitu sebanyak 69 responden (93,2\%) sedangngkan yang memiliki pendidikan Perguruan Tinggi sebanyak 5 responden (6,8\%).

Hasil uji statistik bivariatnya di dapatkan nilai P-Valuenya sebesar 0,643 di mana nilai ini lebih dari nilai signifikansi sebesar $5 \%$ atau 0,05 yang berarti hal ini menunjukkan bahwa tidak ada hubungan antara tingkat pendidikan dengan terjadinya persalinan kala I lama, hal ini di karenakan responden penelitian dari kriteria Pendidikan sebagian besar terdapat pada pendidikan DasarMenengah sebanyak 69 responden (93,2\%) sedangkan pada rentang pendidikan Perguruan Tinggi hanya sebesar 5 responden (6,8\%).tinggi (lebih dari 3 anak) mempunyai angka kejadian lebih tinggi daripada paritas rendah (mempunyai 1 anak) (Winkjosastro,2011). Pengalaman melahirkan yang tidak menyenangkan, akan memberikan dampak pada persalinan berikutnya, sedangkan pada wanita yang pertama mengalami hamil, biasanya menjelang persalinan akan di hantui oleh bayangan seputar nyeri saat persalinan dan ketakutan yang tidak beralasan saat yang membuat ibu cemas.

Hasil uji statistik bivariatnya di dapatkan nilai P-Valuenya sebesar 0,643 di mana nilai ini lebih dari nilai signifikansi sebesar $5 \%$ atau 0,05 yang berarti hal ini menunjukkan bahwa tidak ada hubungan antara tingkat pendidikan dengan terjadinya persalinan kala I lama, hal ini di karenakan responden penelitian dari kriteria Pendidikan sebagian besar terdapat pada pendidikan DasarMenengah sebanyak 69 responden $(93,2 \%)$ sedangkan pada rentang pendidikan Perguruan Tinggi hanya sebesar 5 responden (6,8\%).

\section{Faktor Paritas}

Paritas adalah jumlah kelahiran seluruhnya bayi yang hidup (Widyatama, 2011). Jumlah anak (paritas) yang 
dilahirkan juga berpengaruh terhadap persalinan, paritas 2-3 merupakan paritas paling aman untuk kehamilan dan persalinan, bila ditinjau dari kejadian kematian maternal, paritas tinggi (lebih dari 3 anak) mempunyai angka kejadian lebih tinggi daripada paritas rendah (mempunyai 1 anak) (Winkjosastro,2011). Pengalaman melahirkan yang tidak menyenangkan, akan memberikan dampak pada persalinan berikutnya, sedangkan pada wanita yang pertama mengalami hamil, biasanya menjelang persalinan akan di hantui oleh bayangan seputar nyeri saat persalinan dan ketakutan yang tidak beralasan saat yang membuat ibu cemas.

Hasil penelitian ini menunjukkan bahwa ibu bersalin di UPTD Puskesmas Ketuwan yang primipara sebanyak 31 responden $(41,9 \%)$ yang mengalami kejadian persalinan kala I lama ada sebanyak 21 responden $(28,4 \%)$ dan yang bersalin normal ada sebanyak 10 responden $(13,5 \%)$, sedangkan yang multipara terdapat 43 responden $(58,1 \%)$ yang mengalami kejadian persalinan kala I lama ada 16 responden $(21,6 \%)$ dan yang bersalin normal ada 27 responden (66,5\%). Yang artinya bahwa mayoritas ibu bersalin yang ada di UPTD Puskesmas Ketuwan adalah ibu bersalin multipara yaitu sebanyak 43 responden $(58,1 \%)$ sedangkan yang primipara sebanyak 31 responden (41,9\%).

Hasil uji statistik bivariatnya hubungan antara paritas responden dengan kejadian persalinan kala I lama di dapatkan hasil nilai P-Value sebesar 0,011 di mana nilainya kurang dari nilai signifikansi sebesar $5 \%$ atau 0,05 berarti hal ini menunjukkan bahwa ada hubungan antara paritas ibu bersalin dengan terjadinya persalinan kala I lama.

Hasil penelitian ini sejalan dengan penelitian yang di lakukan oleh Setyaningsih, 2017 yang menyatakan bahwa terdapat hubungan yang signifikan antara paritas ibu yakni Primipara dan Multipara dengan kejadian persalinan lama.

\section{Faktor His}

Hasil Penelitian ini sejalan dengan penelitian yang di lakukan oleh Ardhiyanti \& Susanti,2016 yang menyatakan ibu dengan his lemah lebih beresiko mengalami persalinan lama di bandingkan dengan ibu dengan His kuat pada saat persalinan tua.

Inersia uteri adalah his yang sifatnya lemah lebih singkat dan lebih jarang di bandingkan denaga his yang normal. Inersia uteri di bedakan atas inersia uteri primer dan inersia uteri sekunder, Inersia uteri primer adalah kelainan his yang timbul sejak permulaan persalinan, sedangkan inersia uteri sekunder adalah kelainan his tang timbul sejak adanya his yang kuat teratur dan dalam waktu yang lama (Rukiyah, 2012). His di katakan Adequat atau normal apabila his terjadi 3 kali dalam 10 menit dana lamanya 40 detik atau lebih, 
sebaliknya his di katakan lemah apabila his berlangsung kurang dari 3 kali dalam 10 menit dan lamanya kurang dari 30 detik

Hasil penelitian ini menunjukkan ibu bersalin di UPTD Puskesmas Ketuwan yang saat proses persalinannya memiliki His Normal $\left(3 \times 10^{\prime}, 40 "\right)$ sebanyak 33 responden $(44,6 \%)$ yang melengalami kejadian persalinan kala I lama ada sebanyak 6 responden $(8,1 \%)$ dan yang bersalin normal ada sebanyak 27 responden $(36,5 \%)$, sedangkan yang memiliki His lemah $\left(<3 \times 10^{\prime}, 40 "\right)$ terdapat 41 responden $(55,4 \%)$ yang mengalami kejadian persalinan kala I lama ada 31 responden $(41,9 \%)$ dan yang bersalin normal ada 10 responden (13,5\%) . Yang artinya bahwa mayoritas ibu bersalin di UPTD Puskesmas Ketuwan memiliki His yang lemah $\left(<3 \times 10^{\prime}, 40 "\right)$ yaitu sebanyak 41 responden $(55,4 \%)$ sedangngkan yang memiliki His Normal (3X10',40") sebanyak 33 responden (44,6\%).

Hasil uji statistik bivariat hubungan antara $\mathrm{His}$ responden dengan kejadian persalinan kala I lama di dapatkan nilai PValuenya sebesar 0,000 di mana nilainya kurang dari nilai signifikansi sebesar $5 \%$ atau 0,05 yang berarti ada hubungan antara His ibu bersalin dengan terjadinya persalinan kala I lama.

\section{Faktor Bayi Baru lahir}

Hasil penelitian ini tidak sejalan dengan penelitian yang di lakukan oleh Astriana, Ratna Dewi Putri, 2015 yang menyatakan bahwa Ada hubungan antara janin besar dengan partus lama. Makrosomia atau janin besar adalah bila berat badan melebihi 4000 gram. Makrosomia dapat disebabkan oleh berbagai faktor diantaranya adalah herediter, Riwayat penyakit diabetes mellitus, pola hidup yang berpengaruh terhadap kenaikan berat badan yang berlebihan (Cunningham, 2013). Pada panggul normal, janin dengan berat 2.5004.000 gram umunya tidak menimbulkan kesukaran persalinan. Bayi yang besar dapat memberi tanda atau peringatan terhadap kemungkinan terjadinya persalinan lama akibat sulitnya kelahiran bahu (Mochtar, 2011)

Hasil penelitian menunjukkan ibu bersalin di UPTD Puskesmas Ketuwan yang saat proses persalinannya memiliki Berat Janin Normal (2.500-4.000gr) sebanyak 72 responden (97,2\%) yang melengalami kejadian persalinan kala I lama ada sebanyak 36 responden (48,6\%) dan yang bersalin normal ada sebanyak 36 responden (48,6\%), sedangkan yang memiliki Berat Janin Tidak Normal $(<2.500,>4.000 \mathrm{gr})$ terdapat 2 responden $(2,8 \%)$ yang mengalami kejadian persalinan kala I lama ada 1 responden $(1,4 \%)$ dan yang bersalin normal ada 1 responden (1,4\%). Yang artinya bahwa sebagian besar ibu bersalin di UPTD Puskesmas Ketuwan memiliki Berat Janin Normal (2.500 - 4.000gr) yaitu sebanyak 72 responden $(97,2 \%)$ sedangngkan yang 
Berat Janin Tidak Normal $(<2.500,>4.000$

gr) hanya 2 responden $(2,8 \%)$.

Hasil uji statistik bivariat hubungan antara Berat Bayi Lahir dengan kejadian persalinan kala I lama di dapatkan hasil nilai $\mathrm{P}$-Value yang sebesar 1.000 di mana nilai ini lebih besar dari nilai signifikansi sebesar $5 \%$ atau 0,05 yang berarti bahwa tidak ada hubungan antara Berat Janin dengan terjadinya persalinan kala I lama, hal ini di karenakan responden penelitian dari Berat Bayi Lahir sebagian terdapat pada kriteria Berat Janin Normal (2.500$4.000 \mathrm{gr}$ ) yaitu sebesar 72 responden $(97,2 \%)$ sedangkan pada kriteria Berat Janin Tidak Normal $(<2.500,>4.000$ gr) hanya 2 responden $(2,8 \%)$.

\section{KESIMPULAN}

Kesimpulan dari penelitian ini adalah sebagai berikut

1. Gambaran Kejadian kejadian persalinan kala I lama:

a. Berdasarkan umur sebagian besar kejadian persalinan kala I lama terjadi pada umur reproduksi sehat terjadi pada umur reproduksi sehat (20-35 th) yaitu sebesar $44,6 \%$.

b. Berdasarkan tingkat pendidikan sebagian besar kejadian persalinan kala I lama terjadi pada tingkat pendidikan pendidikan Dasar-Menengah sebesar 45,9\%.

c. Berdasarkan paritas sebagian lama terjadi pada primipara sebesar $28,4 \%$. d. Berdasarkan his sebagian besar kejadian persalinan kala I lama terjadi pada his lemah $\left(<3 \times 10^{\prime}, 40 "\right)$ sebesar $41,9 \%$.

e. Berdasarkan berat bayi lahir sebagian besar kejadian persalinan kala I lama terjadi pada berat bayi lahir normal (2.500$4.000 \mathrm{gr}$ ) sebesar $48,6 \%$.

2. Tidak terdapat hubungan antara umur dengan kejadian Persalinan Kala I lama

3. Tidak terdapat hubungan antara Pendidikan dengan kejadian Persalinan Kala I lama

4. Terdapat hubungan antara Paritas dengan kejadian Persalinan Kala I lama

5. Terdapat hubungan antara His dengan kejadian Persalinan Kala I lama

6. Tidak terdapat hubungan antara Berat Bayi Lahir dengan kejadian Persalinan Kala I lama

\section{Saran}

1. Puskesmas

a. Penelitaian ini di harapkan bisa memberikan informasi dan masukan untuk untuk penentuan diagnosis dan pengambilan keputusan.

b. Penentuan diagnosis pasti dan pengambilan keputusan yang tepat perlu di lakukan untuk mencegah terjadinya komplikasi terhadap ibu dan janin. 
2. Bagi Ibu Hamil

Di harapkan penelitian ini dapat memberikan informasi dan masukan terkait hal-hal yang bisa terjadi saat persalinan sehingga ibu hamil dapat mempersiapkan diri untuk persalinannya sejak awal.

\section{DAFTAR PUSTAKA}

1. Ardhiyanti, Y., \& Susanti, S. (2016). Faktor Ibu yang Berhubungan dengan Kejadian Persalinan Lama di RSUD Arifin Achmad Pekanbaru. Jurnal Kesehatan Komunitas, 3(2), 83-87. https://doi.org/10.25311/jkk.vol3.iss2. 108

2. Astriana, Ratna Dewi Putri, H. A. (2015). Faktor-faktor yang berhubungan dengan kejadian partus lama di RSUD Abdul Moeloek Provinsi Lampung TAhun 2013. 1(3), 143-147.

3. Cunningham, F. G. (2013). Obstetri Williams (Vol. 2). EGC.

4. Gultom, L. (2014). Faktor Yang Berhubungan Dengan Kejadian Partus Lama Pada Ibu Bersalin Di Rsu Haji Medan Tahun 2014. Pannmed, 10(1), 18-25.

5. Manuaba, I. B. S. (2010). IImu kebidanan, penyakit kandungan dan keluarga berencana (15th ed.). EGC.

6. Mochtar, R. (2011). Sinopsis Obstetri: Obstetri Fisiologi Obstetri (Ed. 3). Buku Kedokteran EGC.
Patologi dan fisiologi persalinan (Muhammad Hakimi (ed.); Ed 1). Andi.

8. Riyanto. (2014). Faktor-faktor yang Berhubungan dengan Partus Lama di Puskesmas Poned Kabupaten Lampung Timur. Jurnal Kesehatan Metro Sai Wawai, VII(2), 15-21.

9. Rukiyah, A. Y. (2012). Asuhan Kebidanan Patologi 4 Bagian 2. Trans Info Media.

10. Saifuddin, A. B. (2009). Buku Acuan Nasional Pelayanan Kesehatan Maternal dan Neonatal. YBP-P.

11. Soviyati, E. (2016). Faktor-Faktor Yang Berhubungan Dengan Lama Persalinan Di Rsud'45 Kuningan Jawa Barat Tahun 2015. Jurnal Bidan "Midwife Journal," 2(1), 33-43.

12. Widyatama, T. (2011). Kamus saku kebidanan. Widyatamma.

7. Oxorn, H. (2010). Ilmu Kebidanan: 